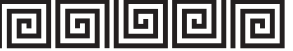

PHILOLOGIA CLASSICA
ANTIQUITAS PERENNIS

回回回回回

VOL. 11 - FASC. 2. 2016

UDC $801.731+821.111$

\title{
SHAKESPEARE'S CLUMSIEST PHRASE OR A DISREGARDED CASE OF HIS QUOTING PLATO VERBATIM
}

\section{Irina I. Burova}

St. Petersburg State University,

7-9, Universitetskaya nab., St. Petersburg, 199034, Russian Federation; i.burova@spbu.ru

A number of researchers have shown that Shakespeare's works bear the marks of the dramatist's knowledge of Plato. Elizabethans could have an access to Plato's heritage due to various editions of his dialogues, both in the original and also in Latin, Italian and French translations, but there is no way to establish whether the Bard borrowed directly from Plato or whether he learned about Plato's teachings from some other sources. J. Vivian, H. R. Rickman, D. Quincy demonstrated convincingly Shakespeare's indebtedness to Plato. They found that debt in such dramatic works as "A Midsummer Night's Dream" and "Henry V". Meanwhile Shakespearean scholars have ignored a possibility of interpreting Shakespeare's last will and testament as a text that could be properly understood due to allusions to Plato's works incorporated in it. The embarrassingly unpolished style of the document and its having nothing in common with Shakespeare's poetic diction, have both been explained by the testator's poor physical condition. The purpose of this paper is to suggest a new reading of the most notorious phrase in the will, the one about the second best bed bequeathed to Shakespeare's prospective widow. The phrase can be regarded as an allusion to two dialogues by Plato, the "Republic" and the "Laws", and this reading might change some of the existing beliefs in Shakespearean studies.

Keywords: Plato in Renaissance England, William Shakespeare, Shakespeare's Greek, William Shakespeare's last will, the second best bed, the "Republic", the "Laws."

It has become an adage that the Platonic school of thought influenced most English writers of the Elizabethan age, including William Shakespeare. These $16^{\text {th }}$-century English intellectuals shared Plato's notion of love as a series of elevations providing human beings with the opportunity to ward off base lust binding them to the animal kingdom and aspire after the only proper form of love, the so-called heavenly one, born in pursuit of the Ideal beauty and devoid of sensual attraction. Renaissance thinkers' adherence to the aristocratic theory of subordination in government as the means of preservation of the natural order of things and their general disapproval of democracy stemmed mostly from the "Politics" and "Republic". It was Plato who supplied the Renaissance thought with the unanimously adopted concept of the human soul as consisting of three parts denoted as 
the Appetite, the Rational, and the Spiritual ones. These were a few of Plato's insights, and only a few, which became an integral part of Renaissance culture.

It is true that no English translations of Plato were published before or during Shakespeare's lifetime (Palmer 1911), but the philosopher was highly praised by humanists and introduced into the Universities (Conley 1927, 57). Elizabethan humanists could read Plato in the original as both the first Greek edition of the Platonic corpus published by Aldus Manutius in 1513 (Hattaway 2003, 49) and the second one by Johannes Oporinus and Simon Grynaeus (Oporinus et al. 1534) were brought to England from the Continent. Alas, not so many Elizabethans could read Greek. Knowledge of Latin was much more common, so most of them were introduced to Plato through Marcilio Ficino's classic Latin translation of Omnia Opera published in 1484, the edition retaining its popularity over subsequent two centuries. A fine Jean de Serres' edition of Plato's complete works dedicated to Queen Elizabeth, in which every Latin translation was set alongside the original Greek text (de Serres 1578), was also available for the English readers. Those who could not read Plato in any of the classical languages could satisfy their curiosity with French or Italian translations, eg., the one by Louis Le Roy who most probably was the first among his compatriots to translate Plato directly from the original texts as no traces of literal borrowings from Ficino's translations were found in his works (Gundersheimer 1966, 32). These were the editions of Plato prevalent in the Elizabethan England.

There is no proof, however, that Shakespeare read any works by Plato. Conversely, nobody has proved he did not. From Ben Jonson's famous commendatory poem published in the First Folio (1623), we may assume Shakespeare's "small Latin and lesse Greeke" were not enough for his reading difficult philosophical texts in either of classical languages. Still a possibility exists he could study Plato in French: by Elizabethan and Jacobean standards, the Bard might not have got a top-notch learning but his command of French was so strongly pronounced in "Henry V" that it gave grounds to regard the author as the only English dramatist of his time to write at length in French (Watson 1990, 614).

Not having a decisive evidence of Shakespeare's direct knowledge of Plato, some scholars still maintain the great playwright was much influenced by the Greek philosopher and provide compelling examples from Shakespeare's plays to prove their standpoint. For one, in his laconic one-page report Hans P. Rickman pointed out at the coincidence of Shakespeare's account of the death of Falstaff in "Henry V" (Act ii, Scene 3) with the description of the death of Socrates in the "Phaedo" (117e-118a), insisting Shakespeare quoted Plato verbatim (Rickman 1996, 378). John Vivian carried out a convincing analysis of "A Midsummer Night's Dream" as a parable based on Platonist ideas (Vivyan 1961, 8). In a more recent paper, Bérnard Quincy drew an impressive parallel between "A Midsummer Night's Dream" and the "Phaedrus". Starting with the discussion of the striking similitude of the place of action in both works, the scholar found a much more important semblance between the texts, pointing out that Shakespeare employed erotic tension "to contrast sober reason with impassioned madness" in just the same way as it had been done in the "Phaedrus," (Quincy 2009, 105) thus establishing Plato's dialogue as a source of inspiration for the Renaissance playwright.

The problem of Shakespeare's indebtedness to Plato might be approached not only by scrutinizing the texts of plays and poems by the Bard. Our aim in this paper is to draw attention of specialists to a possible reading of the seemingly ridiculous interlineal insertion on the third leaf of Shakespeare's last will and testament about the bed he left to his wife: 
"Item I give unto my wife my second best bed with the furniture", which might shed a new light on the document as a whole.

Since the day it was found, Shakespeare's will has ever been puzzling and embarrassing researchers by a striking disconnect between its unbookish style and supreme poetic diction characteristic of Shakespeare's works. It launched an endless debate over the socalled Shakespeare authorship question, Anti-Stratfordians refusing to take it for granted that the text of the last will was dictated by the superb master of the English language. The phrase about the bed in particular has been unanimously and severely ridiculed as the one that by no means could be coined by the Bard. Still there were many who, feeling uneasy about the clumsy phrase, tried to ignore its ambiguity. In the third variorum Shakespeare edition (1821) James Boswell put forward the assumption that "the second best bed" was the usual occurrence in the age of Shakespeare (Shakespeare, 1821, vol. 2, 609). To prove his point, he cited the last will of Sir Thomas Lucy who in 1600 left his second son a second-best horse. Boswell's interpretation still seems feasible for some modern scholars, opposing opinion prevailing. The truth must be somewhere in between.

In his fifth book on Elizabethan life Frederick George Emmison offers an extensive analysis of wills of Essex gentry and yeomen, showing Elizabethan testators often used "best" to define items they bequeathed. Moreover, there are wills in which "best beds" are mentioned. For instance, a widower left his "best bed" to his daughter, another person, a yeoman, intended his "best bed" to his wife (Emmison 1980, 104; 126). Such phrasing must have been a commonplace, but there are no other documents in which a bequeathed "next to the best" item is mentioned without a preceding reference to "the best" one. Also Shakespeare's instruction about the "second best bed" stands out by the absence of any hints how the will executors were to distinguish it from the best one as well as by an uncommonly gelid mentioning of Mrs. Shakespeare who, unlike all the other heirs, was not even called by name. In this particular case, however, scholars and fiction writers tend to prefer extremities.

Most authors agree that Shakespeare's wife was mentioned only in the afterthought insertion into the text, as if the dying man had completely forgotten about his prospective widow distributing his property between relatives and friends. The testator did not entrust his surviving spouse to anyone or call her well-beloved (Miller Cutting 2011, 85). The scantiness of the gift proved to be enough to hypothesize Shakespeare's marriage was an unhappy one. Thus the second best bed bequest became a window into the Bard's family life and a sandy foundation for nearly everything that has been written about his wife, both by critics and fiction writers. As Katherine Scheil wittily remarked, our idea of Anne Shakespeare would be very different if she had been given the "broad silver gilt bowl" instead of the "second best bed" (Scheil 2009, 69).

Though it is impossible to arrive at the truth about Shakespeare's feelings for his wife, there is little doubt, whether it was meant as a snub or a token of affection and care, it was the latest amendment introduced into the text of the will. This old belief was firmly buttressed by a recent paper and ink analysis of the will carried out by conservators at The National Archives. An infrared ray scanning of the manuscript showed it had not been drafted in one setting, page two having been written earlier than the first and last ones. As to the "second best bed," Dr. Amanda Bevan, Legal Records Specialist at The National Archives, believes it was added in March 1616 (What Will's Will tells us about Shakespeare, 2016). 
The important results obtained do not help to settle another problem: the will contains neither instructions where to look for "the second best bed," nor any hints at how to distinguish it from the best bed that was to exist in the household (Garber et al. 2008, 92-94). Hence there have been a lot of suppositions made, researches competing with fiction writers in their bold assumptions and fantasies. For one, the late Robert Nye believed "the second best bed" was a marital bed in New Place (Nye 2000), "the best bed" being the one in London, on which Shakespeare made love with Southampton. According to Audrey Peterson, both beds, the best and the one next to it, were in Stratford, the best item having been mindfully given by the Shakespeares to Will's elderly parents (Peterson 2005, 90). Peter Ackroyd is almost of the same opinion except he believes the best bed in the household was reserved for guests (Ackroyd 2005, 484). Cognate (Holden 1999, 322) and even more elaborate suggestions can be easily found in scholarly papers. For instance, Dieter Fuchs locates the second best bed in Stratford suggesting to look for the best bed, the symbol of marital fidelity, in Ancient Greece lore: the researcher regards the inserted phrase in Shakespeare's will as a hint at Anne's infidelity, her contrariety to Penelope, the best bed being the one made by Odysseus of a living olive tree (Fuchs 2015, 30-33).

The late $20^{\text {th }}$-century pseudo-biographical fiction about Shakespeare seems to have grown fascinated with the motif of "the second best bed" as a hiding-place for something so precious it could not be directly mentioned in the last will. In Tim Kelly's comedy "The Second Best Bed" the fabled piece of furniture becomes a hider for Shakespeare's loving letter to his spouse and jewels he left her to ensure her well-being in the years to come after his death (Kelly 1970). Adhering authors like Connie Willis (Willis 1994) and Avril Rowlands (Rowlands 2005) made a step further, inferring that Shakespeare's manuscripts were hidden in the bed and Shakespeare wished this invaluable heritage would fall to Anne. Pseudo-biographical writings associating the "second best bed" either with material or spiritual values are mere fantasies. That said, the trend requires an explanation.

What could compel Shakespeare to make such a ridiculous addition to his will? If he had meant to insult his wife, it would have been enough for him not to mention her in the will. If he had been worrying about her future, he would have named somebody to take care of her. One way or another, there must have been some solid reason to prevent him from taking the final decision about the second best bed up to the eleventh hour. His being slow might be attested to his not willing to let his decision known in advance, which could be quite understandable if the bed contained something really precious. It is also possible to surmise the clumsy phrase jumping out of the page may have more than one meaning, the hidden one being clear to those who were let into the secret.

If our guess is correct, it is important to consider allusions "the second best bed" triggers. In Shakespeare's works, beds are often mentioned in connection with love-making, death and rest. For instance, the word occurs 27 times in "Romeo and Julliet" and 21 times in "Othello." But it was just once that the Bard addressed to the bed of his own: "Weary with toil, I haste me to my bed..." (Sonnet 27, line 1), associating it with creativity, as physical rest encourages fantasy, wakes up poetic fancies and invites the poet to start on an imaginary journey towards the ideal image of his love. It should be specified that in all the pre-Shakespearean literary tradition the direct link between a bed and creative work had been firmly established only in Plato's the "Republic," Book X, in which the philoso-

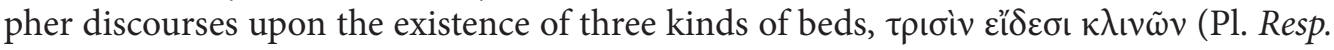
597b12). 
The primary bed exists as the idea of a bed created by god, that is further incarnated

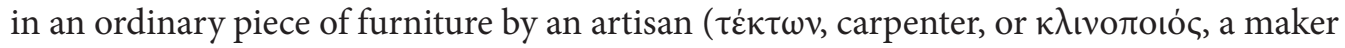
of beds), while the third kind of a bed is its painted image, an imitation of a real bed produced by an artist (Plato's term $\zeta \omega \gamma \rho \alpha \dot{\varphi} \varphi \rho^{\circ}$ stands here for an imitator of nature, the one who draws from nature).

In Shakespeare's aesthetics, to create a work of art was to mirror real life, so the playwright could also be called a sort of Plato's $\zeta \omega \gamma \rho \alpha \dot{\varphi} \varphi \circ \varsigma$, while his work could be likened to the third type of a bed mentioned by Plato. Moreover, a little further on in the "Republic" the philosopher directly compared an artist to an author of tragedies:

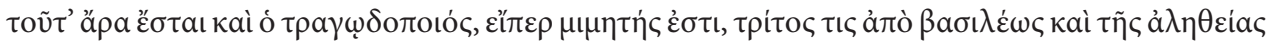

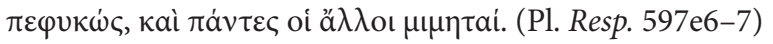

'This, then, will apply to the maker of tragedies also, if he is an imitator and is in his nature three removes from the king and the truth, as are all other imitators.' (Shorey, 1969)

In another dialogue, the "Laws," we can find an equivalent for the English "second

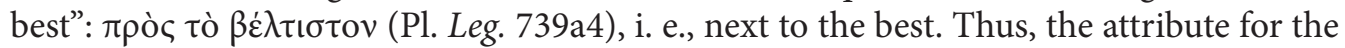
bed Shakespeare used in his last will also sounds quite Platonic. For our purposes it is also worth mentioning that in the same book of the "Laws" Plato touched upon the issues of inherited wealth:

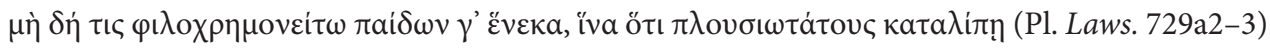

'And let no man love riches for the sake of his children, in order that he may leave them as wealthy as possible...' (Bury 1967-1968);

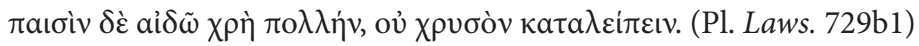

'To his children it behoves a man to bequeath modesty, not money, in abundance'. (Bury, 19671968).

If we were to choose key words for sections of Plato's dialogues containing "second best" and "bed", we might pitch upon "tragedy" and "succession to an estate" establishing additional links between them and Shakespeare's testament. That said, we might attempt to look at the notorious phrase from a different angle. In Shakespeare's plays, double entendres are common. Oftentimes they have a sexual connotation as it is with the famous Thisbe's kissing "the wall's hole" ("A Midsummer Night's Dream," V, 1; Shakespeare 1994, 299) or Maria's sly remark about Sir Andrew Aguecheek's dry hands ("Twelfth Night," I, 3; Shakespeare 1994, 643). One can also find not a few examples of phrases with double meaning in tragedies and chronicles, suffice it to mention "Macbeth" with its prophecy concerning Great Birnam wood. Such devices being characteristic of Shakespeare's style, it is possible to interpret the phrase about the second best bed as the one with an equivocal meaning, the hidden one being an allusion to Plato.

There is a certain problem to be resolved in our further speculations: Plato wrote about three kinds of beds while in case of Shakespeare's last will we can consider only two beds: the bed mentioned directly presupposes there existed the best one, in other words, Shakespeare departed from Plato as to the number of beds. Quality can be attributed only to material objects; this said, the bed made by a carpenter appears to be the best and the one created by an artist becomes the next in quality to it. 
If we agree the phrase about the second best bed may contain allusions to Plato, we get a possible key to its hidden meaning: the second best bed might be a circumlocu-

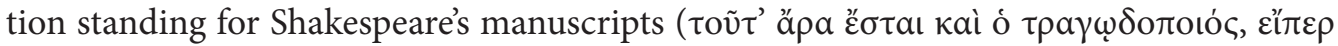

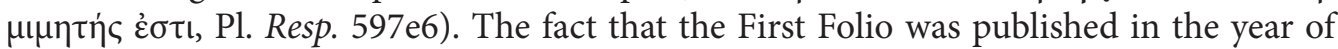
Anne Shakespeare's death is also suggestive to the hypothesis she had been appointed the custodian of the Bard's archive.

Our speculations over "the second best bed" brought us to the following conclusions:

- Shakespeare did not suffer from mental debility in the closing stage of his life;

- his manuscripts were brought from London to Stratford and were kept in his house;

- Shakespeare cared for his wife's future;

- he trusted her enough to give her the power with his most precious possession;

- his last will and testament may have been read in a wrong way;

- other phrases in the document considered may also have a double meaning and be allusive.

All of them require a further fine-grained examination. We have just suggested an unconventional approach to Shakespeare's last will and testament interpretation hoping to draw attention of classical scholars to the document traditionally treated by British studies specialists only.

\section{References}

Ackroyd P. Shakespeare: The Biography. London, Chatto and Windus, 2005.

Burnet J. (ed.). Platonis Opera. Oxford, Oxford Univ. Press, 1903.

Bury R. G.(tr.). Plato: in 12 vols. Vols. 10-11. Cambridge (Mass.), Harvard Univ. Press; London: William Heinemann Ltd, 1967-1968.

Conley C. H. The First English Translators of the Classics. New Haven, Yale Univ. Press; London, Humphrey Milford; Oxford, Oxford Univ. Press, 1927.

De Serres J.(tr., comm.). Platonis, Augustissimi Philosophi, omnium quae extant operum. Genéve: Henri Estienne, 1578.

Emmison F. G. Elizabethan Life: Wills of Essex Gentry and Yeoman. Chelmsford, Essex Country Council, 1980.

Fuchs D. "He Puts Bohemia on the Seacoast and Makes Ulysses Quote Aristotle": Shakespearean Gaps and the Early Modern Method of Analogy and Correspondence in Joyce's 'Ulysses', in: Pelaschiar L. (ed.) Joyce/Shakespeare. Syracuse (N. Y.), Syracuse Univ. Press, 2015, 21-37.

Garber M., Kenan,W. R., Jr. Profiling Shakespeare. Routledge, 2008.

Gundersheimer W. L. The Life and Works of Louis Le Roy. Genéve, Librarie Droz, 1966.

Hattaway M. A Companion to English Renaissance Literature and Culture. Blackwell Publishers, Ltd., 2003.

Holden A. William Shakespeare: His Life and Work. London, Little, Brown and Co., 1999.

Kelly T. Second Best Bed: A Romantic Speculation in One Act for Eight Girls. New York, Dramatists Play Service, Inc., 1970.

Miller Cutting B. Alas, Poor Anne: Shakespeare's "Second Best Bed" in Historical Perspective. The Oxfordian 2011, 13, 76-93.

Nye R. Mrs. Shakespeare: The Complete Works. New York, Arcade Publishing, 2000.

Oporinus, J; Grynaeus S. (ed.). Platonis Omnia Opera Cum Commentariis Procli in Timaeum \& Politia, thesauro veteris Philosophiae maximo. Basel, Johannes Valderum, 1534.

Palmer H. R. English Editions and Translations of Greek and Latin Classics Prior to 1641. London, Bibliographical Society, 1911.

Peterson A. Murder in Stratford: As Told by Anne Hathaway Shakespeare. Waterville (Maine), Five Star, 2005.

Quincy B. Shakespeare and Plato on Love. History of Philosophy Quarterly 2009, 26 (2), 103-120.

Rickman H. P. Shakespeare and Plato. Hermes1996, 124 (3), 378.

Rowlands A. Mrs. Shakespeare... the Poet's Wife: A Two-Act Comedy. Colwall, Garnet Miller, 2005. 
Shakespeare W. The Complete Works of William Shakespeare. The Wordsworth Poetry Library. Ware: Wordsworth Editions Ltd., 1994.

Shakespeare W. The Plays and Poems of William Shakespeare with the Corrections and Illustrations of Various Commentators: Comprehending a Life of the Poet and an Enlarged History of the Stage by the Late E. Malone, with a New Glossarial Index. Boswell, J (ed.): In 21 vols. Vol. 2. London, F. C. \& J. Rivington, 1821.

Scheil K. The Second Best Bed and the Legacy of Anne Hathaway. Critical Survey 2009, 21(3) Shakespeare and the Personal Story, 59-71.

Shorey P. (tr.). Plato: in 12 vols. Vols. 5-6. Cambridge (Mass.), Harvard Univ. Press; London, William Heinemann Ltd, 1969.

Vivyan J. Shakespeare and Platonic Beauty. London, Chatto and Windus, 1961.

Watson, G. Shakespeare and the Norman Conquest: English in the Elizabethan Theatre. Virginia Quarterly Review 1990, 66 (4), 613-628.

What Will's Will tells us about Shakespeare, 2016. URL: http://www.bbc.co.uk/programmes/articles/4YGG7 k013n4bhlpFjqFy2dX/what-will-s-will-tells-us-about-shakespeare (accessed 12.08.2016).

Willis, C. Winter's Tale, in: Willis C. Impossible Things: Eleven Stories from One of the Most Creative Minds in Science Fiction. New York: Bantam Spectra, 1994, 224-251.

For citation: Burova I. I. Shakespeare's Clumsiest Phrase or a Disregarded Case of His Quoting Plato Verbatim. Philologia Classica 2016, 11(2), 301-307. DOI: 10.21638/11701/spbu20.2016.209

САМАЯ НЕЛЕПАЯ ФРАЗА ШЕКСПИРА, ИЛИ РАНЕЕ НЕЗАМЕЧЕННЫЙ СЛУЧАЙ ДОСЛОВНОГО ЦИТИРОВАНИЯ ПЛАТОНА

Ирина Игоревна Бурова

В ряде научных работ было продемонстрировано, что сочинения Шекспира свидетельствуют о знании драматургом трудов Платона. Несмотря на очевидность того, что елизаветинцы могли знакомиться с наследием Платона по различным изданиям его диалогов, как на языке оригинала, так и в переводах на латинский, итальянский и французский языки, нет никакой возможности установить, обращался ли Бард непосредственно к текстам Платона или знал об его учении из какихто иных источников. Дж. Вивиан, Г. Р. Рикман, Д. Куинси выявили убедительные примеры влияния Платона на Шекспира, обнаружив их в таких пьесах, как «Сон в летнюю ночь» и «Генрих V». В то же время шекспирологи игнорируют возможность интерпретации завещания Шекспира как текста, который может быть должным образом осмыслен благодаря содержащимся в нем аллюзиям на сочинения Платона. Вызывающий недоумение убогий стиль документа, не имеющий ничего общего с языком поэзии Шекспира, объясняется плохим физическим состоянием завещателя. Цель данной работы заключается в том, чтобы предложить новый вариант прочтения наиболее печально знаменитой фразы из завещания, в которой упоминается о наследовании будущей вдовой Шекспира второй по качеству кровати. Рассмотрение этой фразы как содержащей аллюзию на два диалога Платона, «Государство» и «Законы», могло бы изменить некоторые устоявшиеся представления шекспирологов.

Ключевые слова: Платон в ренессансной Англии, Уильям Шекспир, греческий язык Шекспира, завещание Шекспира, вторая по качеству кровать, «Государство», «Законы».

Received: 11.09.2016

Final version received: 26.10.2016 